\title{
Pernikahan Usia Dini dan Permasalahannya
}

\author{
Eddy Fadlyana, Shinta Larasaty \\ Bagian Ilmu Kesehatan Anak FK Universitas Padjajaran/RS Dr Hasan Sadikin Bandung
}

\begin{abstract}
Kasus pernikahan usia dini banyak terjadi di berbagai penjuru dunia dengan berbagai latarbelakang. Telah menjadi perhatian komunitas internasional mengingat risiko yang timbul akibat pernikahan yang dipaksakan, hubungan seksual pada usia dini, kehamilan pada usia muda, dan infeksi penyakit menular seksual. Kemiskinan bukanlah satu-satunya faktor penting yang berperan dalam pernikahan usia dini. Hal lain yang perlu diperhatikan yaitu risiko komplikasi yang terjadi di saat kehamilan dan saat persalinan pada usia muda, sehingga berperan meningkatkan angka kematian ibu dan bayi. Selain itu, pernikahan di usia dini juga dapat menyebabkan gangguan perkembangan kepribadian dan menempatkan anak yang dilahirkan berisiko terhadap kejadian kekerasan dan keterlantaran. Masalah pernikahan usia dini ini merupakan kegagalan dalam perlindungan hak anak. Dengan demikian diharapkan semua pihak termasuk dokter anak, akan meningkatkan kepedulian dalam menghentikan praktek pernikahan usia dini. (Sari Pediatri 2009;11(2):136-41).
\end{abstract}

Kata kunci: pernikahan usia dini, hak anak

$\mathrm{P}$ ernikahan usia dini telah banyak berkurang di berbagai belahan negara dalam tigapuluh tahun terakhir, namun pada kenyataannya masih banyak terjadi di negara berkembang terutama di pelosok terpencil. Pernikahan usia dini terjadi baik di daerah pedesaan maupun perkotaan di Indonesia serta meliputi berbagai strata ekonomi dengan beragam latarbelakang. ${ }^{1}$

Berdasarkan Survei Data Kependudukan Indonesia (SDKI) 2007, di beberapa daerah didapatkan bahwa sepertiga dari jumlah pernikahan terdata dilakukan oleh pasangan usia di bawah 16 tahun. Jumlah kasus

\footnotetext{
Alamat korespondensi

Dr. Eddy Fadlyana, Sp.A(K)., M Kes. Subbagian Tumbuh Kembang/ Pediatri Sosial Bagian Ilmu Kesehatan Anak FK UNPAD/ RS Dr Hasan Sadikin Bandung. Jl. Pasteur 38, Bandung, Indonesia. Telepon/ Fax: (022) 2035957, E-mail: edfadlyana@yahoo.com
}

pernikahan dini di Indonesia mencapai 50 juta penduduk dengan rata-rata usia perkawinan 19,1 tahun. Di Jawa Timur, Kalimantan Selatan, Jambi, dan Jawa Barat, angka kejadian pernikahan dini berturut-turut 39,4\%, 35,5\%, 30,6\%, dan 36\%. Bahkan di sejumlah pedesaan, pernikahan seringkali dilakukan segera setelah anak perempuan mendapat haid pertama. ${ }^{2}$

Menikah di usia kurang dari 18 tahun merupakan realita yang harus dihadapi sebagian anak di seluruh dunia, terutama negara berkembang. ${ }^{3-6}$ Meskipun Deklarasi Hak Asasi Manusia di tahun 1954 secara eksplisit menentang pernikahan anak, namun ironisnya, praktek pernikahan usia dini masih berlangsung di berbagai belahan dunia dan hal ini merefleksikan perlindungan hak asasi kelompok usia muda yang terabaikan. ${ }^{3}$ Implementasi UndangUndangpun seringkali tidak efektif dan terpatahkan oleh adat istiadat serta tradisi yang mengatur norma sosial suatu kelompok masyarakat. ${ }^{4-6}$ 
Suatu studi literasi UNICEF menemukan bahwa interaksi berbagai faktor menyebabkan anak berisiko menghadapi pernikahan di usia dini. Diketahui secara luas bahwa pernikahan anak berkaitan dengan tradisi dan budaya, sehingga sulit untuk mengubah. ${ }^{4,6-8}$ Alasan ekonomi, harapan mencapai keamanan sosial dan finansial setelah menikah menyebabkan banyak orangtua mendorong anaknya untuk menikah di usia muda. ${ }^{5}$

Komunitas internasional menyadari pula bahwa masalah pernikahan anak merupakan masalah yang sangat serius. ${ }^{1}$ Implikasi secara umum bahwa kaum wanita dan anak yang akan menanggung risiko dalam berbagai aspek, berkaitan dengan pernikahan yang tidak diinginkan, hubungan seksual yang dipaksakan, kehamilan di usia yang sangat muda, selain juga meningkatnya risiko penularan infeksi HIV, penyakit menular seksual lainnya, dan kanker leher rahim. ${ }^{3-10}$ Konsekuensi yang luas dalam berbagai aspek kehidupan tentunya merupakan hambatan dalam mencapai Millennium Developmental Goals. ${ }^{4,8,10}$

\section{Definisi}

Anak adalah seseorang yang terbentuk sejak masa konsepsi sampai akhir masa remaja. Definisi umur anak dalam Undang-undang (UU) Pemilu No.10 tahun 2008 (pasal 19, ayat1) hingga berusia 17 tahun. Sedangkan UU Perkawinan No.1 Tahun 1974 menjelaskan batas usia minimal menikah bagi perempuan 16 tahun dan lelaki 19 tahun. Definisi anak berdasarkan UU No. 23 tahun 2002, adalah seseorang yang belum berusia 18 tahun, termasuk dalam anak yang masih berada dalam kandungan. ${ }^{11}$ Pernikahan anak didefinisikan sebagai pernikahan yang terjadi sebelum anak mencapai usia 18 tahun, sebelum anak matang secara fisik, fisiologis, dan psikologis untuk bertanggungjawab terhadap pernikahan dan anak yang dihasilkan dari pernikahan tersebut. ${ }^{13}$

\section{Tinjauan epidemiologis pernikahan anak di penjuru dunia}

Hasil penelitian UNICEF di Indonesia (2002), menemukan angka kejadian pernikahan anak berusia 15 tahun berkisar $11 \%$, sedangkan yang menikah di saat usia tepat 18 tahun sekitar 35\%. ${ }^{8}$ Praktek pernikahan usia dini paling banyak terjadi di Afrika dan Asia Tenggara. Di Asia Tenggara didapatkan data bahwa sekitar 10 juta anak usia di bawah 18 tahun telah menikah, sedangkan di Afrika diperkirakan $42 \%$ dari populasi anak, menikah sebelum mereka berusia 18 tahun. Di Amerika Latin dan Karibia, $29 \%$ wanita muda menikah saat mereka berusia 18 tahun. Prevalensi tinggi kasus pernikahan usia dini tercatat di Nigeria (79\%), Kongo (74\%), Afganistan (54\%), dan Bangladesh (51\%). ${ }^{8}$ Secara umum, pernikahan anak lebih sering terjadi pada anak perempuan dibandingkan anak laki-laki, sekitar 5\% anak laki-laki menikah sebelum mereka berusia 19 tahun. Selain itu didapatkan pula bahwa perempuan tiga kali lebih banyak menikah dini dibandingkan laki-laki. ${ }^{3}$

Analisis survei penduduk antar sensus (SUPAS) 2005 dari Badan Koordinasi Keluarga Berencana Nasional (BKKBN) didapatkan angka pernikahan di perkotaan lebih rendah dibanding di pedesaan, untuk kelompok umur 15-19 tahun perbedaannya cukup tinggi yaitu 5,28\% di perkotaan dan 11,88\% di pedesaan. Hal ini menunjukkan bahwa wanita usia muda di perdesaan lebih banyak yang melakukan perkawinan pada usia muda. ${ }^{2}$ Meskipun pernikahan anak merupakan masalah predominan di negara berkembang, terdapat bukti bahwa kejadian ini juga masih berlangsung di negara maju yang orangtua menyetujui pernikahan anaknya berusia kurang dari 15 tahun. $^{5}$

\section{Permasalahan dalam pernikahan anak}

Beberapa permasalahan dalam pernikahan anak meliputi faktor yang mendorong maraknya pernikahan anak, pengaruhnya terhadap pendidikan, terjadinya kekerasan dalam rumah tangga, dampak terhadap kesehatan reproduksi, anak yang dilahirkan dan kesehatan psikologi anak, serta tinjauan hukum terkait dengan pernikahan anak.

\section{Faktor yang mendorong maraknya pernikahan anak}

Di berbagai penjuru dunia, pernikahan anak merupakan masalah sosial dan ekonomi, yang diperumit dengan 
tradisi dan budaya dalam kelompok masyarakat. Stigma sosial mengenai pernikahan setelah melewati masa pubertas yang dianggap aib pada kalangan tertentu, meningkatkan pula angka kejadian pernikahan anak. ${ }^{4-}$ 8,10 Motif ekonomi, harapan tercapainya keamanan sosial dan finansial setelah menikah menyebabkan banyak orangtua menyetujui pernikahan usia dini. Alasan orangtua menyetujui pernikahan anak ini seringkali dilandasi pula oleh ketakutan akan terjadinya kehamilan di luar nikah akibat pergaulan bebas atau untuk mempererat tali kekeluargaan. ${ }^{7}$

Secara umum, pernikahan anak lebih sering dijumpai di kalangan keluarga miskin, meskipun terjadi pula di kalangan keluarga ekonomi atas. Di banyak negara, pernikahan anak seringkali terkait dengan kemiskinan. ${ }^{5,6,8}$ Negara dengan kasus pernikahan anak, pada umumnya mempunyai produk domestik bruto yang rendah. ${ }^{8,9}$ Pernikahan anak membuat keluarga, masyarakat, bahkan negara mengalami kesulitan untuk melepaskan diri dari jerat kemiskinan dan hal ini tentunya menyebabkan kualitas kesehatan dan kesejahteraan yang rendah baik anak maupun keluarga dan lingkungannya. ${ }^{6,8,13}$

\section{Pernikahan anak dan derajat pendidikan}

Semakin muda usia menikah, maka semakin rendah tingkat pendidikan yang dicapai oleh sang anak. Pernikahan anak seringkali menyebabkan anak tidak lagi bersekolah, karena kini ia mempunyai tanggungjawab baru, yaitu sebagai istri dan calon ibu, atau kepala keluarga dan calon ayah, yang diharapkan berperan lebih banyak mengurus rumah tangga maupun menjadi tulang punggung keluarga dan keharusan mencari nafkah. Pola lainnya yaitu karena biaya pendidikan yang tak terjangkau, anak berhenti sekolah dan kemudian dinikahkan untuk mengalihkan beban tanggungjawab orangtua menghidupi anak tersebut kepada pasangannya. ${ }^{8}$

Dari berbagai penelitian didapatkan bahwa terdapat korelasi antara tingkat pendidikan dan usia saat menikah, semakin tinggi usia anak saat menikah maka pendidikan anak relatif lebih tinggi dan demikian pula sebaliknya. Pernikahan di usia dini menurut penelitian UNICEF tahun 2006 tampaknya berhubungan pula dengan derajat pendidikan yang rendah. Menunda usia pernikahan merupakan salah satu cara agar anak dapat mengenyam pendidikan lebih tinggi. ${ }^{5,8,13}$

\section{Masalah domestik dalam pernikahan usia dini}

Ketidaksetaraan jender merupakan konsekuensi dalam pernikahan anak. Mempelai anak memiliki kapasitas yang terbatas untuk menyuarakan pendapat, menegosiasikan keinginan berhubungan seksual, memakai alat kontrasepsi, dan mengandung anak. Demikian pula dengan aspek domestik lainnya. ${ }^{8,13}$ Dominasi pasangan seringkali menyebabkan anak rentan terhadap kekerasan dalam rumah tangga. Kekerasan dalam rumah tangga tertinggi terjadi di India, terutama pada perempuan berusia 18 tahun. ${ }^{3}$ Perempuan yang menikah di usia yang lebih muda seringkali mengalami kekerasan. Anak yang menghadapi kekerasan dalam rumah tangga cenderung tidak melakukan perlawanan, sebagai akibatnya merekapun tidak mendapat pemenuhan rasa aman baik di bidang sosial maupun finansial., ${ }^{5,6}$ Selain itu, pernikahan dengan pasangan terpaut jauh usianya meningkatkan risiko keluarga menjadi tidak lengkap akibat perceraian, atau menjanda karena pasangan meninggal dunia. ${ }^{8,13}$

\section{Kesehatan reproduksi dan pernikahan usia dini}

Penting untuk diketahui bahwa kehamilan pada usia kurang dari 17 tahun meningkatkan risiko komplikasi medis, baik pada ibu maupun pada anak. Kehamilan di usia yang sangat muda ini ternyata berkorelasi dengan angka kematian dan kesakitan ibu. Disebutkan bahwa anak perempuan berusia 10-14 tahun berisiko lima kali lipat meninggal saat hamil maupun bersalin dibandingkan kelompok usia 20-24 tahun, sementara risiko ini meningkat dua kali lipat pada kelompok usia 15-19 tahun. ${ }^{5,9,10}$ Angka kematian ibu usia di bawah 16 tahun di Kamerun, Etiopia, dan Nigeria, bahkan lebih tinggi hingga enam kali lipat. ${ }^{5}$

Anatomi tubuh anak belum siap untuk proses mengandung maupun melahirkan, sehingga dapat terjadi komplikasi berupa obstructed labour serta obstetric fistula. Data dari UNPFA tahun 2003, memperlihatkan 15\%-30\% di antara persalinan di usia dini disertai dengan komplikasi kronik, yaitu obstetric fistula. Fistula merupakan kerusakan pada organ kewanitaan yang menyebabkan kebocoran urin atau feses ke dalam vagina. Wanita berusia kurang dari 20 tahun sangat rentan mengalami obstetric fistula. Obstetric fistula ini dapat terjadi pula akibat hubungan seksual di usia dini. ${ }^{5,10}$ Pernikahan anak berhubungan 
erat dengan fertilitas yang tinggi, kehamilan dengan jarak yang singkat, juga terjadinya kehamilan yang tidak diinginkan. ${ }^{14,15}$

Mudanya usia saat melakukan hubungan seksual pertamakali juga meningkatkan risiko penyakit menular seksual dan penularan infeksi HIV. Banyak remaja yang menikah dini berhenti sekolah saat mereka terikat dalam lembaga pernikahan, mereka seringkali tidak memahami dasar kesehatan reproduksi, termasuk di dalamnya risiko terkena infeksi HIV. Infeksi HIV terbesar didapatkan sebagai penularan langsung dari partner seks yang telah terinfeksi sebelumnya. Lebih jauh lagi, perbedaan usia yang terlampau jauh menyebabkan anak hampir tidak mungkin meminta hubungan seks yang aman akibat dominasi pasangan. Pernikahan usia muda juga merupakan faktor risiko untuk terjadinya karsinoma serviks. ${ }^{5-10,13}$ Keterbatasan gerak sebagai istri dan kurangnya dukungan untuk mendapatkan pelayanan kesehatan karena terbentur kondisi ijin suami, keterbatasan ekonomi, maka penghalang ini tentunya berkontribusi terhadap meningkatnya angka morbiditas dan mortalitas pada remaja yang hamil. ${ }^{14,15}$

\section{Anak yang dilahirkan dari pernikahan usia dini}

Saat anak yang masih bertumbuh mengalami proses kehamilan, terjadi persaingan nutrisi dengan janin yang dikandungnya, sehingga berat badan ibu hamil seringkali sulit naik, dapat disertai dengan anemia karena defisiensi nutrisi, serta berisiko melahirkan bayi dengan berat lahir rendah. Didapatkan bahwa sekitar $14 \%$ bayi yang lahir dari ibu berusia remaja di bawah 17 tahun adalah prematur. Anatomi panggul yang masih dalam pertumbuhan berisiko untuk terjadinya persalinan lama sehingga meningkatkan angka kematian bayi dan kematian neonatus. ${ }^{16,17}$ Depresi pada saat berlangsungnya kehamilan berisiko terhadap kejadian keguguran, berat badan lahir rendah dan lainnya. Depresi juga berhubungan dengan peningkatan tekanan darah, sehingga meningkatkan risiko terjadinya eklamsi yang membahayakan janin maupun ibu yang mengandungnya. ${ }^{16}$

Asuhan antenatal yang baik sebenarnya dapat mengurangi terjadinya komplikasi kehamilan dan persalinan. Namun sayangnya karena keterbatasan finansial, keterbatasan mobilitas dan berpendapat, maka para istri berusia muda ini seringkali tidak mendapatkan layanan kesehatan yang dibutuhkannya, sehingga meningkatkan risiko komplikasi maternal dan mortalitas. ${ }^{5,10}$

Menjadi orangtua di usia dini disertai keterampilan yang kurang untuk mengasuh anak sebagaimana yang dimiliki orang dewasa dapat menempatkan anak yang dilahirkan berisiko mengalami perlakuan salah dan atau penelantaran. Berbagai penelitian menunjukkan bahwa anak yang dilahirkan dari pernikahan usia dini berisiko mengalami keterlambatan perkembangan, kesulitan belajar, gangguan perilaku, dan cenderung menjadi orangtua pula di usia dini. ${ }^{17,20}$

\section{Komplikasi psikososial akibat pernikahan dan kehamilan di usia dini}

Komplikasi psikososial akibat pernikahan dan kehamilan di usia dini didukung oleh suatu penelitian yang menunjukkan bahwa keluaran negatif sosial jangka panjang yang tak terhindarkan, ibu yang mengandung di usia dini akan mengalami trauma berkepanjangan, selain juga mengalami krisis percaya diri. ${ }^{17}$ Anak juga secara psikologis belum siap untuk bertanggungjawab dan berperan sebagai istri, partner seks, ibu, sehingga jelas bahwa pernikahan anak menyebabkan imbas negatif terhadap kesejahteraan psikologis serta perkembangan kepribadian mereka. ${ }^{7}$

\section{Tinjauan hukum dalam pernikahan usia dini}

Konvensi Hak Anak (KHA) berlaku sebagai hukum internasional dan KHA diratifikasi melalui Keppres No.36 tahun 1990, untuk selanjutnya disahkan sebagai undang-undang Perlindungan Anak (UU PA) No.23 tahun 2002. ${ }^{7,18}$ Pengesahan UU tersebut bertujuan untuk mewujudkan perlindungan dan kesejahteraan anak. Dalam UU PA dinyatakan dengan jelas bahwa Negara Kesatuan Republik Indonesia menjamin kesejahteraan tiap-tiap warga negaranya, termasuk perlindungan terhadap hak anak yang merupakan hak asasi manusia. ${ }^{18}$

Konvensi Hak Anak telah menjadi bagian dari sistem hukum nasional, sehingga sebagai konsekuensinya kita wajib mengakui dan memenuhi hak anak sebagaimana dirumuskan dalam KHA. Salah satu prinsip dalam KHA yaitu "kepentingan yang terbaik bagi anak". Maksud dari prinsip "kepentingan yang terbaik bagi anak" adalah dalam semua tindakan 
yang berkaitan dengan anak yang dilakukan oleh pemerintah, masyarakat, badan legislatif dan yudikatif, kepentingan yang terbaik bagi anak harus menjadi pertimbangan utama. ${ }^{9,18}$ Dalam UU PA pasal 1 ayat 2 disebutkan bahwa "perlindungan anak" adalah segala kegiatan untuk menjamin dan melindungi anak dan hak-haknya agar dapat hidup, tumbuh, berkembang, dan berpartisipasi, secara optimal sesuai dengan harkat dan martabat kemanusiaan, serta mendapat perlindungan dari kekerasan dan diskriminasi. ${ }^{18}$

Dalam deklarasi hak asasi manusia, dikatakan bahwa pernikahan harus dilakukan atas persetujuan penuh kedua pasangan. Namun kenyataan yang dihadapi dalam pernikahan usia dini ini, persetujuan menikah seringkali merupakan akumulasi dari paksaan atau tekanan orangtua/wali anak, sehingga anak setuju untuk menikah seringkali merupakan rasa bakti dan hormat pada orangtua. Orangtua beranggapan menikahkan anak mereka berarti suatu bentuk perlindungan terhadap sang anak, namun hal ini justru menyebabkan hilangnya kesempatan anak untuk berkembang, tumbuh sehat, dan kehilangan kebebasan dalam memilih. ${ }^{7-9,19}$ Pernyataan senada juga dikeluarkan oleh International Humanist and Ethical Union, bahwa pernikahan anak merupakan bentuk perlakuan salah pada anak (child abuse). ${ }^{3,9,10}$ Dalam hal ini, mengingat berbagai konsekuensi yang dihadapi anak terkait dengan pernikahan dini sebagaimana telah dibahas, maka pernikahan anak tentunya menyebabkan tidak terpenuhinya prinsip "yang terbaik untuk anak", sehingga hal ini merupakan pelanggaran terhadap hak asasi anak. ${ }^{4,5,9}$

Dalam UU Perlindungan Anak dengan jelas disebutkan pula mengenai kewajiban orangtua dan masyarakat untuk melindungi anak, serta kewajiban orangtua untuk mencegah terjadinya perkawinan pada usia anak-anak (pasal 26). Sangsi pidana berupa hukuman kurung penjara dan denda diatur dalam pasal 77-90 bila didapatkan pelanggaran terhadap pasal-pasal perlindungan anak. ${ }^{18}$

\section{Peran dokter anak menyikapi pernikahan usia dini}

Terkait dengan kesehatan reproduksi dan pernikahan dini, maka dokter anak berperan serta dalam memberikan penyuluhan pada remaja dan orangtua mengenai pentingnya mencegah terjadinya pernikahan di usia dini serta membantu orangtua untuk dapat memberikan pendidikan kesehatan reproduksi kepada anak sesuai tahapan usianya. Dokter anak juga berperan membantu remaja untuk mendapatkan informasi dan pelayanan kesehatan reproduksi juga alat kontrasepsi, menilai kemampuan orangtua berusia remaja dalam mengasuh anak untuk mencegah terjadinya penelantaran atau perlakuan salah pada anak, serta berpartisipasi dalam masyarakat untuk mencegah terjadinya pernikahan di usia dini. ${ }^{20}$

\section{Daftar Pustaka}

1. Pambudy MN. Perkawinan anak melanggar undangundang perkawinan. [diunduh 29 April 2009]. Didapat dari: http://cetak.kompas.com/read, 2008.

2. Palu B. Menyelamatkan generasi muda. [Diunduh tanggal 10 Mei 2009]. Didapat dari: www.bappenas. go.id, 2008.

3. IHEU. UN publishes IHEU statement: child marriage is child abuse. [diunduh 29 April 2009]. Didapat dari: www. iheu.org. 2005.

4. UNICEF. Child protection information sheet: child marriage. [diunduh 29 April 2009]. Didapat dari: $w w w$. unicef.org. 2006.

5. UNPFA. Child marriage fact sheet. [diunduh tanggal 29 April 2009]. Didapat dari: www.unpfa.org. 2005.

6. ICRW. Ending child marriage. [diunduh 29 April 2009]. Didapat dari: www.icrwindia.org. 2007

7. UNICEF. Early marriage: child spouses. Innocenti Digest 2001;7:2-29.

8. UNICEF. Early marriage: a harmful traditional practice, a statistical exploration. [diunduh 29 April 2009]. Didapat dari: www.unicef.org. 2006.

9. WHO. Implementation og general assembly resolution 60/251 of march 2006 entitled "human rights council". [diunduh 29 April 2009]. Didapat dari: $w w w$. unitednations.org. 2007.

10. USAID. Preventing child marriage: protecting girls health. [diunduh 29 April 2009]. Didapat dari: www. usaid.gov. 2006.

11. Soetjiningsih. Tumbuh kembang anak. Jakarta: Balai Penerbit FKUI; Jakarta: 2006.h.21-2.

12. Undang-undang Republik Indonesia tentang perkawinan. Penerbit Yayasan Peduli Anak Negeri; 1974.h.1-15.

13. IPPF. Ending child marriage: a guide for global policy action. [diunduh 29 April 2009]. Didapat dari: www. ippf.org. 2006. 